\title{
PENERAPAN SISTEM PERTANIAN ORGANIK DI KELOMPOK TANI MEKAR TANI JAYA DESA CIBODAS KABUPATEN BANDUNG BARAT
}

\section{APPLICATION OF ORGANIC FARMING SYSTEM IN MEKAR TANI JAYA FARMER GROUP CIBODAS VILLAGE BANDUNG BARAT REGENCY}

\author{
Fauzia Imani $^{1}$, Anne Charina ${ }^{2}$, Tuti Karyani ${ }^{3}$, Gema Wibawa Mukti ${ }^{4}$ \\ Program Studi Agribisnis, Fakultas Pertanian, Universitas Padjadjaran \\ *E-mail: fauziaimani96@gmail.com
}

\begin{abstract}
ABSTRAK
Penerapan sistem pertanian konvensional menyebabkan dampak negatif bagi lingkungan maupun konsumen, salah satu upaya yang dapat dilakukan untuk menangani dampak negatif tersebut yaitu dengan mengubah sistem pertanian konvensional menjadi organik. Tahun 2010, pemerintah mengeluarkan program Go Organic dan pada tahun tersebut luas lahan pertanian organik yang sudah tersertifikasi mencapai titik maksimal. Hingga saat ini terdapat banyak para pelaku usahatani yang mengklaim bahwa hasil produk pertaniannya merupakan produk pertanian organik. Kelompok Tani Mekar Tani Jaya telah melakukan budidaya tanaman organik selama 18 tahun. Tujuan dari penelitian ini adalah untuk mengetahui apakah penerapan sistem pertanian organik di Kelompok Tani Mekar Tani Jaya sesuai dengan SNI 6729 : 2016, dan juga untuk menganalisis kendala yang dihadapi oleh Kelompok Tani tersebut dalam penerapan sistem pertanian organik. Penelitian ini menggunakan metode deskriptif kualitatif dengan teknik pendekatan studi kasus. Penelitian ini menggunakan model analisis data Miles and Huberman dan model analisis fishbone. Hasil penelitian menunjukan persentase kesesuaian sistem pertanian organik yang diterapkan oleh Kelompok Tani Mekar Tani Jaya dengan SNI 6729 : 2016 mengenai sistem pertanian organik yaitu sebesar 94 persen (\%). Sementara itu, kendala utama yang dihadapi oleh Kelompok Tani Mekar Tani Jaya yaitu tidak semua sistem pertanian organik menurut SNI 6729 : 2016 dapat diterapkan sehingga berdampak terhadap aspek-aspek yang lain.
\end{abstract}

Kata kunci: Pertanian Organik, SNI 6729 : 2016, kelompok tani

\begin{abstract}
The application of conventional farming systems causes negative impacts for the environment and consumers, an effort made to deal with the negative impact is by changing conventional farming systems into organic. In 2010, the government released the Go Organic program and the area of certified organic farming reached into maximum point in that year. Until now there are many farmers who claim that their agricultural products are the organic one. Mekar Tani Jaya Farmer Group has conducted organic cultivation for 18 years. The aim of this research is to find out the application of organic farming system in Mekar Tani Jaya in accordance with SNI 6729: 2016, and also to know what are the obstacles faced by Mekar Tani Jaya in the implementation of organic farming system. This research is used qualitative descriptive method with through a case study technique. This research also using Miles and Huberman data analysis model and fishbone analysis model. The results is the percentage of conformity organic farming system by Mekar Tani Jaya Farmer Group with SNI 6729 : 2016 is about 94 percent (\%). Meanwhile, the main problem that faced by Mekar Tani Jaya Farmer Group is not all of
\end{abstract}


PENERAPAN SISTEM PERTANIAN ORGANIK DI KELOMPOK TANI MEKAR TANI JAYA

DESA CIBODAS KABUPATEN BANDUNG BARAT

Fauzia Imani, Anne Charina, Tuti Karyani, Gema Wibawa Mukti

the organic farming system according to SNI 6729: 2016 can be applied thus make an impact to other aspects.

Keywords: Organic Farming, SNI 6729 : 2016, farmer group

PENDAHULUAN

Indonesia merupakan negara agraris yang artinya pertanian memegang peranan penting dari keseluruhan perekonomian nasional (Mubyarto, 1989). Sistem pertanian di Indonesia hingga saat ini masih bersifat konvensional. Menurut Gliesman (2007), dampak negatif dari penerapan sistem pertanian konvensional yaitu dapat menyebabkan degradasi dan penurunan kesuburan tanah, mengurangi kelembaban tanah, merusak ekosistem yang berada di lingkungan sekitarnya, menyebabkan erosi, hingga masalah serius yang berdampak pada gangguan kesehatan para konsumen akibat penggunaan pestisida.

Salah satu upaya yang dapat dilakukan untuk menangani dampak yang ditimbulkan dari penerapan sistem pertanian konvensional tersebut yaitu dengan mengubahnya menjadi sistem pertanian berkelanjutan. Praktek pertanian berkelanjutan mencakup penggunaan nutrisi organik dan biologis, rotasi tanaman, pengelolaan hama terpadu, dan peningkatan keberagaman biologis. Pertanian organik merupakan suatu bagian integral dari pertanian berkelanjutan dengan penggunaan bahan organik alami (Mayrowani, 2012). Pertanian organik bertujuan untuk: 1) menghasilkan produk yang berkualitas dengan kuantitas memadai, 2) membudidayakan tanaman secara alami, 3) mendorong dan meningkatkan siklus hidup biologis dalam ekosistem pertanian, 4) meningkatkan kesuburan tanah untuk jangka panjang, 5) menghindarkan seluruh bentuk cemaran yang diakibatkan dari penerapan teknik pertanian, 6) memelihara dan meningkatkan keragaman genetik, dan 7) mempertimbangkan dampak sosial dan ekologis (IFOAM dalam Fuady, 2011).

Pemerintah melakukan tahapan pengembangan dalam pertanian organik yang pertama di Indonesia yaitu dimulai pada tahun 2001-2010. Pemerintah mulai merintis pembangunan pertanian organik di Indonesia dengan menerbitkan Panduan Sistem Pertanian Organik dalam bentuk SNI 6729 : 2002. Pada tahun 2010 Kementerian Pertanian RI mencanangkan program Go Organic. Program tersebut merupakan puncak dari serangkaian tahapan pengembangan pertanian organik 
yang pertama di Indonesia. Mengacu pada Gambar 1, bahwa pada tahun 2010 luas lahan pertanian organik yang sudah tersertifikasi di Indonesia mencapai titik maksimal yaitu pada angka 103.908,09 Ha. Namun, terdapat penurunan luas lahan pertanian organik pada tahun 2011 sampai dengan tahun 2014. Salah satu penyebab hal tersebut yaitu dikarenakan banyaknya para pelaku usahatani yang tidak melanjutkan sertifikasi organik.

Menurut Kardiman (2014), tidak semua produk organik harus disertifikasi apabila ingin menjual produk tersebut karena pengakuan mengenai produk organik dapat dilakukan dengan 3 (tiga) cara yaitu: 1) Mengaku atau mengklaim sendiri, dalam hal ini konsumen dapat mengakses langsung ke lahan organik petani untuk melihat proses bertani sehingga muncul kepercayaan (trust) dan keyakinan bahwa produk tersebut telah diproses secara organik. Namun, dalam proses jual beli hanya dapat dilakukan secara langsung (direct selling); 2) Klaim melalui pedagang atau pengumpul, klaim tersebut dilakukan dengan menyatakan bahwa produk-produk yang dijual diperoleh dari para pelaku organik di bawah bimbingan atau binaan para pedagang atau pengumpul tersebut. Namun, dalam proses penjualannya produk tersebut hanya dapat dilakukan melalui direct selling, agar para konsumen dapat melihat langsung mengenai bagaimana proses produk tersebut dapat dihasilkan agar tercipta kepercayaan (trust); 3) Sertifikasi oleh pihak ketiga Lembaga Sertifikasi Organik (LSO), ketika jarak para konsumen dan petani selaku produsen cukup jauh sehingga tidak dapat dilakukan direct selling, maka perlu adanya pihak ketiga untuk dapat menjamin produk organik tersebut. Pihak ketiga dalam hal ini yaitu melalui sertifikasi oleh LSO, sehingga para konsumen merasa yakin dan terwakili oleh LSO.

Sebanyak 268 produsen organik yang terdaftar pada data Aliansi Strategis Indonesia (2013), menunjukkan bahwa 81 produsen menggunakan kepercayaan konsumen sebagai jaminan kualitas produknya. Komite Akreditasi Nasional (KAN) dan Otoritas Kompeten Pangan Organik (OKPO) membuat ketentuan mengenai sistem pertanian organik yang terdapat pada SNI 6729 : 2016, standarisasi tersebut dibuat untuk penjaminan produk organik. 


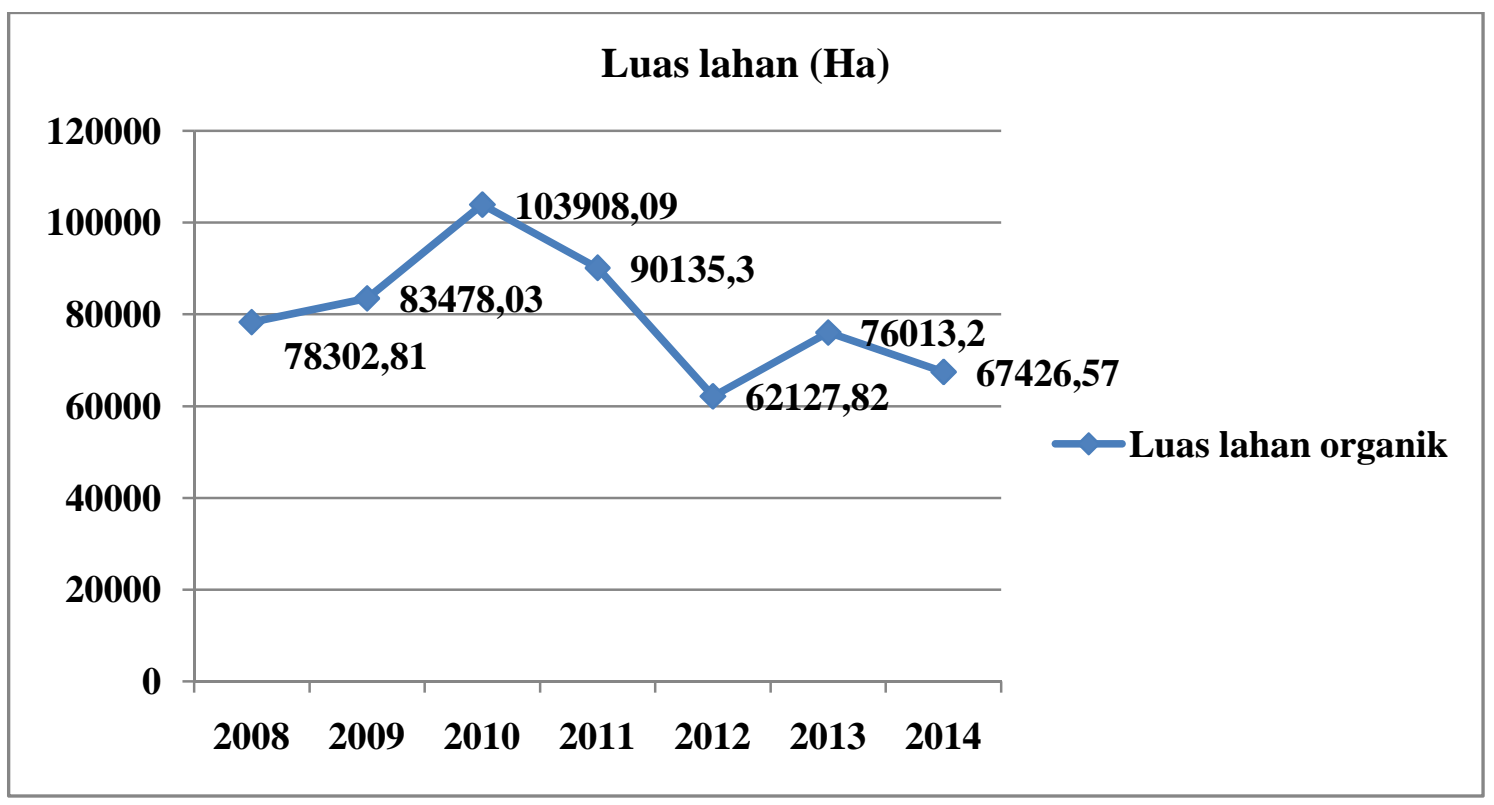

Gambar 1. Data Pertumbuhan Luas Lahan Organik di Indonesia

Sumber: SPOI 2014 - Aliansi Organik Indonesia

Jawa Barat merupakan salah satu daerah yang rata-rata para petaninya menggunakan teknik budidaya pertanian organik dan memproduksi hortikultura organik tertinggi di Indonesia sebanyak 25.784.137 ton (BPS, 2016). Kabupaten Bandung Barat merupakan salah satu daerah yang rata-rata para petaninya menggunakan teknik budidaya pertanian organik (BPS, 2016). Kelompok Tani Mekar Tani Jaya merupakan petani sayuran organik yang berdomisili di Kabupaten Bandung Barat dan sudah menjadi petani organik selama 18 tahun dengan luas lahan 1,3 ha. Sejak tahun 2008 sampai dengan 2018, Kelompok Tani Mekar Tani Jaya membuka Pusat Pelatihan Pertanian dan Perdesaan Swadaya (P4S) mengenai teknik budidaya pertanian organik. Kelompok Tani Mekar Tani Jaya mendapatkan sertifikat organik pada tahun 2012 yang diperoleh dari Lembaga Sertifikasi Organik (LSO). Namun, pada tahun 2014 Kelompok Tani Mekar Tani Jaya tidak lagi memperpanjang sertifikat organik tersebut.

Berdasarkan hal tersebut, perlu adanya penjaminan mengenai sistem pertanian organik yang diterapkan oleh Kelompok Tani Mekar Tani Jaya disesuaikan dengan standarisasi organik menurut SNI 6729 : 2016 dan apa saja yang menjadi kendala dalam penerapan sistem pertanian organik di Kelompok Tani Mekar Tani Jaya menggunakan analisis fishbone. 


\section{METODE PENELITIAN}

\section{Desain Penelitian dan Tempat Penelitian}

Penelitian ini merupakan penelitian kualitatif deskriptif yang dilakukan dengan teknik studi kasus yang memfokuskan masalah pada kesesuaian sistem pertanian organik oleh Kelompok Tani Mekar Tani Jaya dengan SNI 6729 : 2016 mengenai sistem pertanian organik, serta kendala yang dihadapi Kelompok Tani Mekar Tani Jaya dalam penerapan sistem pertanian organik. Tempat penelitian ini dilakukan di Desa Cibodas, Kecamatan Lembang Kabupaten Bandung Barat.

\section{Jenis Data dan Sumber Data}

Jenis data yang dikumpulkan terdiri atas data primer dan data sekunder. Teknik pengumpulan data yang dilakukan adalah: 1) Observasi, yaitu pengamatan langsung yang dilakukan untuk mendapatkan data atau informasi guna mendukung keberlangsungan penelitian, 2) Wawancara, yaitu salah satu teknik pengumpulan data melalui dua orang untuk saling bertukar data/ informasi melalui tanya jawab, 3) Dokumen, merupakan catatan peristiwa berbentuk tulisan maupun gambar.

\section{Analisis Data}

Analisis data dalam penelitian ini dilakukan dengan 2 alat analisis, yaitu:

1) Model analisis Miles and Huberman untuk menganalisis keadaan di lapangan mengenai penerapan sistem pertanian organik di Kelompok Tani Mekar Tani Jaya yang disesuaikan dengan SNI 6729 : 2016. Dalam analisis data kualitatif model Miles and Huberman terdapat 3 (tiga) tahap yaitu reduksi data, penyajian data, dan verifikasi.

2) Model analisis fishbone digunakan untuk menganalisis kendala yang dihadapi oleh Kelompok Tani Mekar Tani Jaya dalam penerapan sistem pertanian organik yang sesuai dengan SNI 6729 : 2016. Model analisis fishbone merupakan komsep analisis sebab akibat yang dikembangkan untuk mendeskripsikan suatu permasalahan dan penyebabnya dalam sebuah kerangka tulang ikan. Menurut Imamoto (2008), penyebab permasalahan dapat dikelompokkan dalam empat kelompok yaitu bahan baku (materials), sumber daya manusia (man), metode (methods), dan lingkungan (environment). 
PENERAPAN SISTEM PERTANIAN ORGANIK DI KELOMPOK TANI MEKAR TANI JAYA

DESA CIBODAS KABUPATEN BANDUNG BARAT

Fauzia Imani, Anne Charina, Tuti Karyani, Gema Wibawa Mukti

HASIL DAN PEMBAHASAN

\section{Sejarah Kelompok Tani Mekar Tani Jaya}

Kelompok Tani Mekar Tani Jaya berdiri pada tanggal 10 Oktober 1987 yang dipimpin oleh Bapak Doyo Mulyo Iskandar. Jenis komoditi yang disuahakan yaitu sayuran lokal dengan target pasar yaitu pasar tradisional. Pola tanam yang dilakukan belum terpola dengan baik. Pemasaran produksi masih melalui tengkulak dengan hasil yang kurang memuaskan karena hanya berorientasi pada kegiatan produksi. Perubahan mulai dilakukan pada tahun 1997 dengan mengubah orientasi usaha yang awalnya hanya berorientasi pada kegiatan produksi menjadi orientasi terhadap pasar. Kelompok Tani Mekar Tani Jaya berupaya untuk meningkatkan sumber daya manusia dengan cara mengikuti kegiatan magang atau pelatihan-pelatihan di beberapa negara yang maju dalam sektor pertanian seperti Jepang, Australia, China, dan Thailand. Pada tahun 2000, Kelompok Tani Mekar Tani Jaya mulai melakukan budidaya sayuran organik dengan harapan adanya perbaikan struktur tanah, menghindari penggunaan pupuk kimia, serta peningkatan hasil nilai jual.

Kelompok Tani Mekar Tani Jaya melakukan usahataninya dalam komoditas hortikultura antara lain, Tomat Beef, Paprika, Kyuri, Horenzo, Tomat Cherry, Asparagus, Brokoli, Lettuce, Cabe, dan Buncis Kenya. Beberapa kooditas tersebut merupakan hasil kegiatan usaha tani yang disesuaikan dengan perminaan pasar dan menggunakan pola tanam yang terjadwal sehingga menghasilkan kuantitas produksi yang maksimal. Komoditas unggulan yang diusahakan oleh Kelompok Tani Mekar Tani Jaya yaitu Buncis Kenya, Tomat Beef, dan Brokoli. Sehingga, dari ketiga komoditas tersebut merupakan komoditas yang cukup berpotensi dalam pengembangan usahatani Kelompok Tani Mekar Tani Jaya.

Peningkatan kualitas mutu dilakukan melalui beberapa penjaminan produk seperti Surat Keterangan Registrasi Good Agriculture Practice (GAP), sertifikat Prima-3 karena produk yag dihasilkan dinyatakan aman dari kandungan pestisida dan memperoleh sertifikat pangan organik pada tahun 2012 dari Lembaga Sertifikasi Organik INOFICE sebagai produsen pangan organik dengan mengimplementasikan secara konsisten pertanian organik untuk ruang lingkup sayuran. Selain itu, Kelompok Tani Mekar Tani Jaya menjadi 
tempat Pusat Pelatihan Pertanian Swadaya (P4S) mengenai budidaya sayuran organik.

\section{Penerapan Sistem Pertanian Organik di Kelompok Mekar Tani Jaya dengan SNI 6729 : 2016}

Suatu produk dapat dikatakan organik apabila terdapat penjaminan produk. Salah satu cara penjaminan produk yaitu dengan melakukan sertifikasi organik melalui Lembaga Sertifikasi Organik (LSO) atau dengan menciptakan kepercayaan (trust) terhadap para konsumen. Munculnya para pelaku usahatani yang melakukan tindakan yang menyalahi aturan dengan melabel dan menjual produk konvensional sebagai produk organik, untuk mengurangi dampak dari kerugian yang dirasakan oleh para konsumen organik, maka pemerintah dalam hal ini Badan Standarisasi Nasional bekerjasama dengan Otoritas Kompeten Pertanian Organik (OKPO) telah membuat standarisasi mengenai sistem pertanian organik. Penilaian tingkat penerapan sistem pertanian organik petani hortikultura didasarkan pada SNI 6729 : 2016 mengenai sistem pertanian organik yang dianjurkan oleh pemerintah.

Kelompok Tani Mekar Tani Jaya merupakan kelompok tani yang tersertifikasi organik terhitung sejak tahun 2012. Namun, pada tahun 2014 Kelompok Tani Mekar Tani Jaya tidak lagi memperpanjang sertifikasi organik tersebut, akan tetapi masih melakukan budidaya tanaman organik. Pembahasan kali ini akan dilakukan analisis terhadap penerapan sistem pertanian organik yang diterapkan oleh Kelompok Tani Mekar Tani Jaya yang disesuaikan dengan SNI $6720: 2016$.

Berdasarkan hasil penelitian, persentase kesesuaian sistem pertanian organik yang diterapkan oleh Kelompok Tani Mekar Tani Jaya dengan SNI 6729 : 2016 yaitu sebesar 94\%. Hal tersebut menyatakan bahwa terdapat beberapa prosedur yang tidak sesuai dengan standarisasi dengan jumlah persentase sebesar $6 \%$. Prosedur yang tidak sesuai terdapat pada salah satu point pencegahan kontaminasi yang disebabkan adanya pembukaan lahan oleh petani lain yang digunakan untuk budidaya tanaman menggunakan sistem pertanian konvensional sehingga keberadaan lahan organik milik Kelompok Tani Mekar Tani Jaya terkena kontaminasi dan sulit untuk dicegah karena keberadaannya sangat berdekatan. Selain itu, prosedur lain yang tidak sesuai terdapat pada salah satu point pemilihan tanaman dan 
PENERAPAN SISTEM PERTANIAN ORGANIK DI KELOMPOK TANI MEKAR TANI JAYA

DESA CIBODAS KABUPATEN BANDUNG BARAT

Fauzia Imani, Anne Charina, Tuti Karyani, Gema Wibawa Mukti

varietas, karena Kelompok Tani Mekar

Tani Jaya tidak menggunakan benih yang bersertifikat organik melainkan menggunakan benih non-organik.

\section{Konversi}

Sejak tahun 2000, Kelompok Tani Mekar Tani Jaya mulai tertarik melakukan budidaya pertanian organik, ketertarikan tersebut muncul setelah mengikuti beberapa pelatihan dari lembaga pemerintah. Pada tahun 2009, Kelompok Tani Mekar Tani Jaya mulai melakukan konversi lahan karena lahan yang diusahakan sebelumnya merupakan lahan konvensional bukan lahan yang ditumbuhi oleh tumbuhan liar sehingga harus dilakukan konversi lahan terlebih dahulu.

\section{Pemeliharaan}

Pemeliharaan meliputi areal pada masa konversi dan yang telah dikonversi menjadi areal organik, tidak boleh digunakan secara bergantian antara metode produksi pertanian organik dan konvensional. Kelompok Tani Mekar Tani Jaya selalu konsisten dalam memelihara lahan pertanian organik, terbukti hingga saat ini para petani di Kelompok Tani Mekar Tani Jaya masih menanam sayuran organik dan tidak menggunakannya secara bergantian dengan sistem pertanian konvensional.

\section{Produksi}

Produksi harus memperhatikan pembatas, penanganan, pengemasan, dan penyimpanan yang jelas sehingga tidak terjadi pencampuran antara produk organik dan non-organik. Kelompok Tani Mekar Tani Jaya telah memperhatikan dan menjalankan hal-hal yang sesuai dengan standarisasi organik seperti memperhatikan dalam penggunaan kemasan baru untuk mengemas produk organik, pemberian label organik pada produk yang sudah dikemas, dan perbedaan petugas dalam menangani produk organik dan non-organik.

\section{Pencegahan Kontaminasi}

Praktek pertanian organik tidak dapat menjamin bahwa produk yang dihasilkan sepenuhnya bebas dari residu karena adanya polusi lingkungan seperti kontaminasi dari udara dan sumber air. Berdasarkan hal tersebut, Kelompok Tani Mekar Tani Jaya melakukan pencegahan kontaminasi yang dimulai dari penanaman tanaman penyangga yaitu seperti tanaman jagung, yang memiliki tinggi sekitar $1 \mathrm{~m}$ dan dapat mencegah kontaminasi organisme (hama) dari udara. Pencegahan kontaminasi dari air dilakukan dengan membuat filterisasi kolam air yang ditanami oleh tanaman eceng gondok seluas $5 \times 5 \mathrm{~m}$, pembuatan 
kolam air yang ditanami tanaman eceng gondok ini bertujuan untuk menyaring kotoran (organisme pengganggu tanaman organik) dari air. Namun, pada tahun 2014 terjadi pembukaan lahan di areal organik milik Kelompok Tani Mekar Tani Jaya untuk budidaya konvensional yang digarap oleh petani lain dan menyebabkan lahan organik terkena kontaminasi dari bahan-bahan kimia seperti pestisida.

\section{Pengelolaan Lahan, Kesuburan Tanah dan Air}

Kegiatan pertanian organik bertujuan untuk meminimalisir dampak negatif terhadap lingkungan dan mengutamakan kelestarian lingkungan. Hal tersebut dapat dimulai dari menjaga kesuburan tanah untuk mencegah degradasi lahan. Salah satu upaya yang dilakukan oleh Kelompok Tani Mekar Tani Jaya dalam mencegah degradasi lahan yaitu dengan melakukan program rotasi tanam yang sesuai dan menggunakan bahan-bahan organik untuk menyuburkan tanah.

\section{Pemilihan Tanaman dan Varietas}

Dalam pemilihan tanaman dan varietas harus dengan menggunakan benih yang berasal dari tumbuhan dan bersertifikat organik. Kelompok Tani Mekar Tani Jaya menggunakan benih non-organik yang bukan GMO (Genetic Modified Organism) akan tetapi diberi perlakuan sesuai prosedur pembenihan organik. Pemilihan varietas disesuaikan dengan permintaan pasar.

\section{Manajemen Ekosistem}

Kelompok Tani Mekar Tani Jaya selama ini telah mengikuti aturan manajemen organik dengan tidak melakukan kegiatan yang menimbulkan dampak negatif pada lingkungan sekitar khususnya terhadap wilayah konservasi dan wilayah warisan budaya seperti hutan lindung dan aliran sungai. Selain itu, Kelompok Tani Mekar Tani Jaya melakukan penanganan terhadap organisme pengganggu tanaman dengan cara yang ramah lingkungan dan berusaha melakukan tindakan pencegahan sebelum mengambil tindakan pengendalian.

\section{Pengelolaan Organisme Pengganggu Tanaman (OPT)}

Organisme pengganggu tanaman terdiri dari gulma, hama dan penyakit. Dalam melakukan pengelolaan OPT, Kelompok Tani Mekar Tani Jaya mendahulukan untuk melakukan tindakan pencegahan sebelum melakukan tindakan pengendalian. Tindakan pencegahan menggunakan program rotasi tanam dan tumpang sari. Sementara itu, tindakan 
PENERAPAN SISTEM PERTANIAN ORGANIK DI KELOMPOK TANI MEKAR TANI JAYA

DESA CIBODAS KABUPATEN BANDUNG BARAT

Fauzia Imani, Anne Charina, Tuti Karyani, Gema Wibawa Mukti

pengendalian dilakukan apabila tindakan pencegahan sudah tidak mampu menahan keberadaan OPT. Kelompok Tani Mekar Tani Jaya melakukan tindakan pengendalian dengan cara menggunakan input budidaya organik seperti membuat pupuk nabati dan pestisida organik.

\section{Kendala dalam Penerapan Sistem Pertanian Organik di Kelompok Tani Mekar Tani Jaya}

Berdasarkan hasil analisis terdapat 4 penyebab utama yang mengakibatkan tidak semua sistem pertanian organik di Kelompok Tani Mekar Tani Jaya menurut SNI 6729 : 2016 dapat diterapkan. Penyebab utama tersebut dapat dilihat dari segi aspek manusia (man), cara kerja (method), bahan baku (materials), dan lingkungan (environment). Berikut rincian permasalahan dari ke-empat aspek tersebut:

menggunakan alat analisis fishbone,

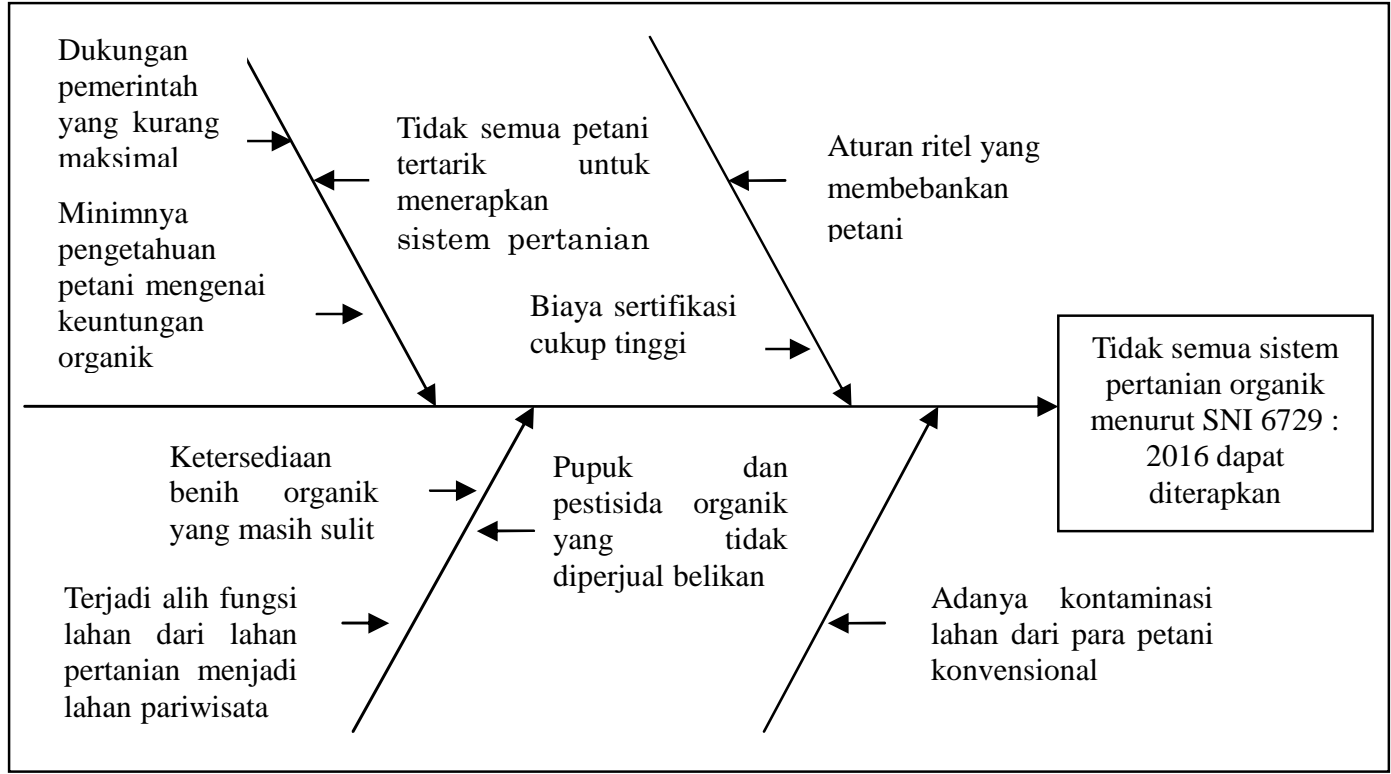

Berikut rincian permasalahan dari ke-empat aspek tersebut:

1. Manusia (Man)

(i) Dukungan pemerintah yang kurang maksimal

Dukungan pemerintah yang kurang maksimal dapa dilihat dari kurangnya bentuk pembinaan dan pendampingan dalam memberikan pelatihan mengenai penanganan hama dan penyakit kepada para anggota kelompok tani melalui Petugas Penyuluh Lapangan (PPL). Selain itu, bantuan pemerintah masih sangat kurang dalam penyediaan input produksi dan pemberian subsidi untuk kemudahan sertifikasi organik. Sehingga, 
hal tersebut kurang mendukung petani untuk tetap menerapkan sistem pertanian organik.

(ii) Tidak semua petani tertarik untuk menerapkan sistem pertanian organik

Budidaya pertanian organik membutuhkan perlakuan yang lebih intensif dibandingkan dengan pertanian konvensional, karena dalam input budidayanya tidak diperbolehkan untuk menggunakan bahan kimia. Prosedur dalam penerapan sistem pertanian organik juga dianggap terlalu menyulitkan petani, dimulai dari lamanya masa konversi lahan yang memakan waktu selama dua tahun dan ketersediaan lahan yang sesuai dengan kriteria organik di Desa Cibodas masih kurang mendominasi sehingga hanya beberapa petani yang bisa menerapkan sistem pertanian organik. Selain itu, para petani organik selalu kecewa akan respon dan pola pikir konsumen yang tidak mengetahui seperti apa produk organik sesungguhnya. Dari beberapa hal tersebut menyebabkan beberapa petani kurang tertarik untuk menerapkan sistem pertanian organik.

(iii) Minimnya pengetahuan petani mengenai keuntungan dari

menerapkan sistem pertanian
organik

Beberapa petani belum banyak mengetahui mengenai manfaat maupun keuntungan dalam menggunakan budidaya pertanian organik, hal tersebut dapat terlihat dari belum banyaknya petani konvensional yang beralih menjadi petani organik. Tidak semua petani berpikir bahwa pertanian organik tidak memiliki keuntungan. Hal tersebut menyebabkan tidak semua dapat petani menerapkan sistem pertanian organik.

\section{Teknis/ Cara Kerja (Method)}

(i) Biaya sertifikasi yang cukup tinggi

Sertifikasi organik dibutuhkan untuk menjamin bahwa produk yang dihasikan sudah memenuhi kriteria dari produk organik. Produk organik yang sudah tersertifikasi organik oleh lembaga sertifikasi berhak untuk mencatumkan label organik di setiap produknya. Sehingga, bila produk dari Kelompok Tani Mekar Tani Jaya ingin dijual dengan mencantumkan label organik, kelompok tani tersebut harus selalu melakukan perpanjangan sertifikasi organik dengan biaya 12 juta setiap 2 tahun. Biaya tersebut dapat dikatakan tinggi bagi kalangan petani. 
PENERAPAN SISTEM PERTANIAN ORGANIK DI KELOMPOK TANI MEKAR TANI JAYA

DESA CIBODAS KABUPATEN BANDUNG BARAT

Fauzia Imani, Anne Charina, Tuti Karyani, Gema Wibawa Mukti

(ii) Aturan ritel yang membebankan petani

Para produsen organik biasanya mulai menggunakan sistem pertanian organik karena dilatarbelakangi oleh orientasi pasar yang memiliki nilai jual yang lebih tinggi contohnya yaitu ritel modern, dimana ritel modern tersebut biasanya dikunjungi oleh para konsumen yang sesuai dengan kriteria konsumen produk organik. Selama ini produk organik yang dihasilkan oleh Kelompok Tani Mekar Tani Jaya sudah memiliki pasar ritel modern yang tetap seperti Sogo, Ranch Market, Total Buah, dan sampai memasuki pasar ekspor ke Singapura. Namun, para petani di Kelompok Tani Mekar Tani Jaya mengalami kesulitan untuk memenuhi permintaan pasar sedangkan aturan pasar ritel mengharuskan petani untuk memasok secara kontinyu.

3. Bahan Baku (Materials)

(i) Terjadi alih fungsi lahan dari lahan pertanian menjadi lahan pariwisata

Ketersediaan lahan pertanian di Desa Cibodas mulai menurun karena adanya alih fungsi lahan menjadi lahan pariwisata. Hal tersebut tidak dapat dikendalikan oleh petani, karena mengingat peluang dalam bisnis pariwisata sangat besar di Kecamatan
Lembang dan termasuk dengan Desa Cibodas yang sebagian lahan pertaniannya sudah banyak yang berkurang akibat dari pembangunan homestay, karena penghasilan dari usaha penginapan lebih menguntungkan dibandingkan dengan penghasilan dari kegiatan usahatani. Maka dari itu, untuk tetap dapat menerapkan sistem pertanian organik dibutuhkan lahan, terutama lahan yang tidak terkontaminasi dengan limbah apapun.

(ii) Ketersediaan benih organik yang masih sulit

Menurut aturan yang tertulis berdasarkan SNI 6729 : 2016 menyebutkan bahwa salah satu aturan dalam pemilihan varietas yaitu dengan menggunakan benih organik dan berasal dari tumbuhan. Namun, pada kenyataannya keberadaan benih yang bersertifikat organik di Indonesia masih sulit ditemukan. Diharapkan pemerintah mengeluarkan benih yang sudah bersertifikat organik agar para petani organik di Indonesia dapat memenuhi aturan yang sesuai dengan SNI 6729 : 2016.

(iii) Pupuk dan pestisida organik yang tidak diperjualbelikan

Penggunaan pupuk dan pestisida dalam melakukan budidaya tanaman 
organik sangat diperlukan, akan tetapi dalam penerapan sistem pertanian organik pupuk dan pestisida harus dibuat dari bahan-bahan organik dan tidak dicampur dengan bahan kimia lainnya. Maka dari itu, untuk menjaga keamanan dalam penggunaan pupuk dan pestisida organik para petani harus membuatnya sendiri. Dalam pembuatan pupuk dan pestisida tersebut, para petani dituntut untuk teliti dan sabar.

\section{Lingkungan (Environment)}

(i) Terdapat kontaminasi lahan dari para petani konvensional

Kelompok Tani Mekar Tani disiplin dalam meminimalisir kontaminasi dari lingkungan, terlihat dari penggunaan buffer zone untuk mencegah kontaminasi dari udara, membuat filterisasi untuk mencegah kontaminasi dari sumber air, dan melakukan pasca panen di lokasi yang berbeda dengan produk pertanian konvensional. Namun, pada tahun 2014 terjadi pembukaan lahan oleh petani lain yang berlokasi di blok yang sama dengan area pertanian organik milik Kelompok Tani Mekar Tani Jaya. Pembukaan lahan pertanian tersebut tidak menggunakan sistem pertanian organik tetapi menggunakan sistem pertanian konvensional sehingga perlakuan nonorganik yang dilakukan oleh petani konvensional akan mempengaruhi hasil untuk produk organik yang ada di sekitarnya. Hal tersebut menyebabkan beberapa petani di Kelompok Tani Mekar Tani jaya sulit untuk tetap menggunakan sistem pertanian organik.

\section{PENUTUP}

(1) Persentase kesesuaian sistem pertanian organik yang diterapkan oleh Kelompok Tani Mekar Tani Jaya dengan SNI 6729 : 2016 mengenai sistem pertanian organik yaitu sebesar 94 persen (\%) dan ketidaksesuaian sistem pertanian organik yaitu sebesar 6 persen $(\%)$ yang disebabkan adanya pembukaan lahan oleh petani konvensional dari kelompok tani lain yang berada di areal lahan organik sehingga menyebabkan adanya kontaminasi terhadap lahan organik milik Kelompok Tani Mekar Tani Jaya dan penggunaan benih yang belum bersertifikat organik.

(2) Kendala yang dihadapi oleh Kelompok Tani Mekar Tani Jaya dalam melakukan penerapan sistem pertanian organik yaitu tidak semua sistem pertanian organik menurut SNI 6729 : 2016 dapat diterapkan. Kendala tersebut disebabkan oleh 4 
penyebab utama yang dapat dilihat dari segi:

1. Manusia (man)

(i) Dukungan pemerintah yang kurang maksimal.

(ii) Tidak semua petani tertarik untuk menerapkan sistem pertanian organik.

(iii) Pengetahuan petani mengenai keuntungan organik yang minim.

2. Cara Kerja (method)
(i) Biaya sertifikasi cukup tinggi.
(ii) Aturan ritel yang membebankan petani.

3. Bahan Baku (materials)

(i) Terjadi alih fungsi lahan dari lahan pertanian menjadi lahan pariwisata.

(ii) Ketersediaan benih organik yang sulit.

(iii) Pupuk dan pestisida organik yang tidak diperjual belikan.
4. Lingkungan (environment)

(i) Terdapat kontaminasi lahan dari para petani konvensional.

\section{DAFTAR PUSTAKA}

BPS. 2015. Statistik Pertanian Organik Jawa Barat. Jakarta: BPS.

Fuady, I. 2011. Hubungan Perilaku Komunikasi Dengan Praktek Budidaya Pertanian Organik. Skripsi. Institut Pertanian Bogor.

Gliessman, S.R. 2007. The Ecological Sustainable Food System. University of California, Santa Cruz.

Imamoto, T., et al. 2008. Perivesical abscess caused by migration of a fish bone from the intestinal tract. International Journal of Urology. Vol. 9 (405409).

Kardiman, A. 2014. Majalah Organik. Edisi 35/Th. 11 Juli - September, pp 15-17.

Mubyarto. 1989. Pengantar Ekonomi Pertanian. Lembaga Penelitian, Pendidikan Penerangan Ekonomi dan Sosial, Jakarta.

Mayrowani, H. 2012. Pengembangan Pertanian Organik di Indonesia. Bogor: Jurnal Sosial Ekonomi dan Kebijakan Pertanian. 